\title{
Potential of Growth Regulators and Orange Oil Extract as a Bio- Stimulant in Enhancing the Growth and Biochemical Contents in Luffa (Luffa acutangula)
}

\author{
Safina Naz ${ }^{1}$, Khushbo Hussain ${ }^{1}$, Muhammad Asif Zulfiqar ${ }^{2 *}$ and Syed Atif Hasan Naqvi ${ }^{3}$
}

${ }^{1}$ Department of Horticulture; ${ }^{2} P A R C$, Research and Training Station; ${ }^{3}$ Department of Plant Pathology, Bahauddin Zakariya University, Multan, Pakistan.

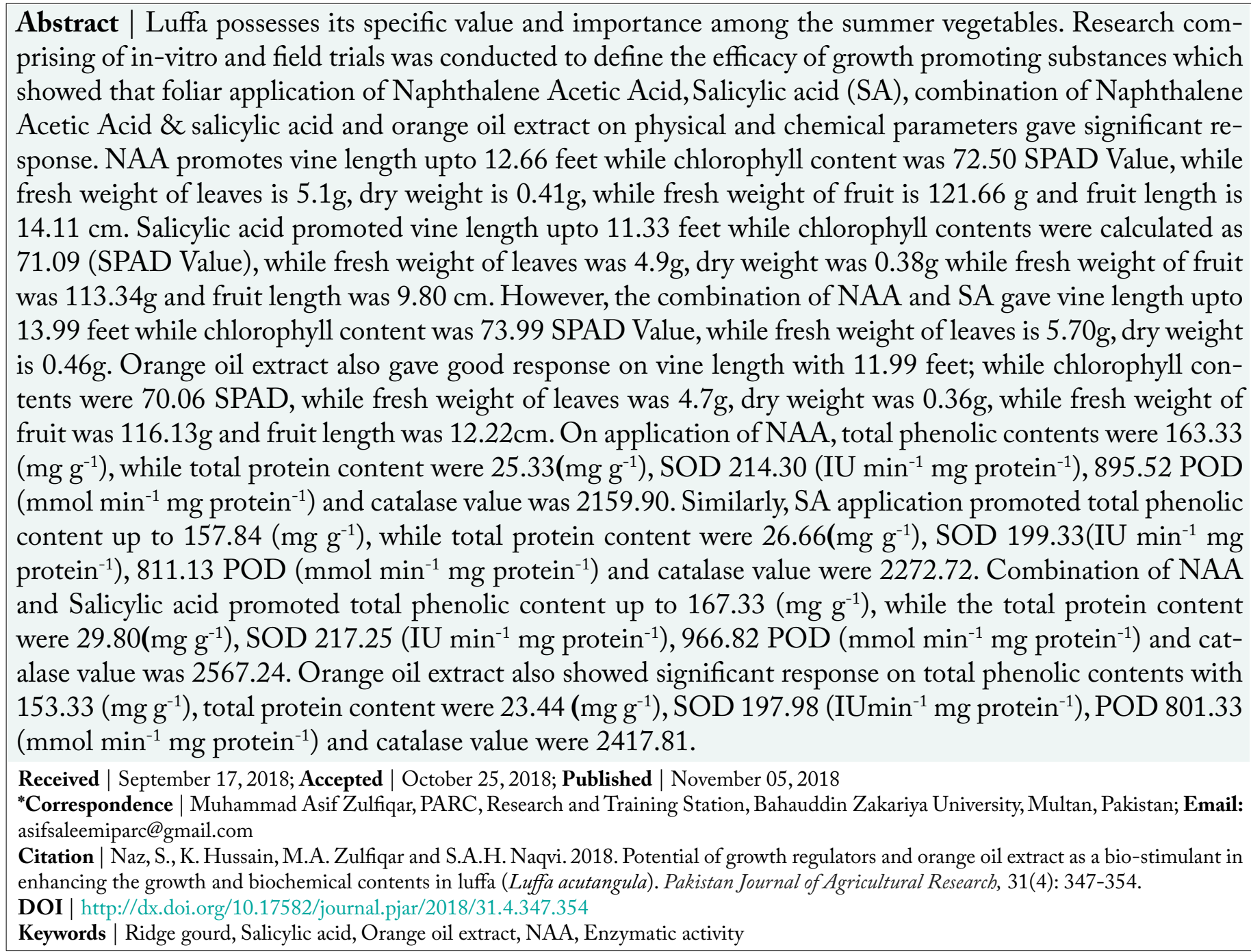

\section{Introduction}

$\mathrm{L}$ uffa belongs to kingdom planate; family cucurbitaceae and genus luffa. Luffa has species:
Luffa acutangula (Angled luffa, ridged luffa, vegetable gourd) Luffa aegyptiaca/Luffa cylindrica (Smooth luffa, Egyptian luffa, dishrag gourd, gourd loofa) Luffa operculata (Wild loofa, sponge cucumber). It's really 
a dark green, ridged vegetable possessing white pulp along with white seeds baked into its soft flesh. Dark green vegetable white pulp has seed seared into its soft flesh grown on ridges extremely fibrous to consume. Ridge gourd possess lower calories and lower level of saturated fats. Ridge gourds are rich in, Vitamin-C, minerals thiamin, iron, dietary fiber, riboflavin, zinc and have addition of magnesium. For medicinal purposes all parts of ridge gourd, seeds, pulp and dried crusts are used. Ridge gourd is easy to digest having a lovable flavor with cooling character. Ridge gourd is considered good for diabetes because they form a low-calorie diet. Particularly in South Indian cuisine both skin and malleable pulp are used in making a range of recipes. Huge health benefits are well-known from Chutneys ready from the peel and pulp of ridge gourd. A few health advantages of is that it works as an excellent blood purifier, possessing laxative properties and Possessing laxative properties in ridge gourd.

The growth regulators gibbrellic acid such as stimulates the cell elongation of main shoot and roots, while ethrel induce more branches per plant, maximum number of fruits, fruit length and finally seed yield. It is obvious that no seed production techniques like spraying of proper growth regulators and standardized stages of spray on growth, fruit set and seed yield especially for ridge gourd is not present. Therefore, the present study was undertaken to build up a proper seed production technology with growth regulator and stages of spray on growth, seed yield, fruit set and of ridge gourd. Several studies demonstrated that plants can respond to exogenous application of these chemicals however, plant growth regulators are synthesized indigenously by plants. An exogenous application of plant growth regulators affects the endogenous hormonal pattern of the plant by supplementation of sub-optimal levels or by interaction with their synthesis, translocation or inactivation of existing hormone levels (Arshad and Frankenberger, 1993). In leafy vegetables plant growth regulators are one of the most important factors for rising higher yield. Growth and yield of field crops has excellent organized result with application of growth regulators. Hormones increased total dry mass of a field crop because hormones regulate physiological process and synthetic growth regulators may increase growth and development of field crops (Das and Das, 1996; Tiaz and Zeiger, 2002; Dakua, 2002; Rafeekher et al., 2002; Islam et al., 2007). Some examination indicated that naphthalene acetic acid (NAA) is a potential an- tifungal agent (Michniewicz and Rozej, 1987). Auxin strongly repressed mycellial growth, sporulation, and spore germination of fusarium culmorum in vitro (Michniewicz and Rozej, 1987). In some advanced countries like Europe, USA and Japan in the field of agriculture the use of plant growth regulators has become commercialized.

The current uses for plant growth regulators are not only in a high value horticultural crops but it also increases field crop yield directly either by increasing total biological yield or the harvest index. Auxin, Gibberellins, Cytokinins, Abcisic acid and Ethylene are five classes of growth substances. Naphthalene Acetic Acid (NAA) belongs to synthetic forms of Auxins. Auxins play vital role in vascular tissue, differentiation, root initiation, apical dominance, cell elongation, leaf senescence, cell division, flowering fruit setting, flower and fruit abscission (Davies, 1987). Different levels of Auxin promote response significantly on the growth and yield parameters of rice (Zahir et al., 1998). On cotton planofix (Naphthalene Acetic Acid) had great effect on plant height, volume of boll, number of fruiting branches and yield (Abro et al., 2004). Wheat cultivars showed better performance by applying naphthalene Acetic Acid 20ppm in enhancing the straw and grain yields (Alam et al., 2002). The growth and yield of cereals have been used for the enhanced by using Naphthalene Acetic Acid (Lilani et al., 1991). PGRs help in promoting new roots and increase the root growth. Rice spraying with 10 and 100 ppm NAA at tillering stage greatly increased root dry weight. 10 In plants Naphthalene Acitic Acid, is a wide broad, somatotrophin-like growth regulator. It produces considerable outcome in promoting progress of sharp ends for the root system, resulting in more, straighter and thicker roots. NAA can enhance fruit setting ratio, prevent fruit dropping, and promote flower sex. Salicylic acid (SA) is a phenolic phytohormone is found in plants with roles in plant growth and development, photosynthesis, transpiration, in uptake and also in transport. SA also induces specific changes in chloroplast structure and leaf anatomy. SA is involved in endogenous signaling, mediating in plant defense against pathogens (Hayat et al., 2007). Salicylic acid (SA) acting a role in the fighting to pathogens by inducing the production of pathogenesis-related proteins (Hayat et al., 2007). Hence, the research was conducted to determine the physical parameters and the enzymatic activities of the luffa plants in response of the application of PGR's. 
Materials and Methods

\section{Study site}

The present investigation was carried out at the Department of Horticulture, Faculty Agriculture sciences and Technology, Bahauddin Zakaryia University $30^{\circ} 25^{\prime} 93 \mathrm{~N}$ and $71^{\circ} 51^{\prime} 46 \mathrm{E}$, Multan, Pakistan in 2016.

\section{Plant material}

The Jaipure long popular variety of ridge gourd was collected from the local market of Multan and grown in the experimental vegetable area of the Department.

\section{Sowing of crop}

Seeds of luffa were sown on a raised bed. Ridges and furrow method was adopted with plant to plant spacing of $120 \times 90 \mathrm{~cm}$ and row to row distance of 2 feet and $\mathrm{B} \times \mathrm{B} 7$ feet was maintained. First irrigation was applied to the bed immediately after sowing the seeds and then after every 4 to 5 days. Germination was observed 7-8 days after the sowing and it was approximately $98 \%$. All the normal cultural practices were adopted to maintain the healthy crop stand in the field.

\section{Experimental design}

The experiment was conducted in a randomized completeblock design with fourblocks. The treatments were randomized within and among the blocks. The randomization was performed with random number table.

\section{Treatments and their preparation}

$\mathrm{T} 0=$ Control, $\mathrm{T} 1=$ Naphthalene Acetic Acid, T2= Salicylic acid, T3= Naphthalene Acetic Acid + Salicylic acid, T4= Orange oil extract, the experiment consisted of 4 treatment combinations involving two growth regulators as main NAA @100 ppm and SA @ 100 ppm, third treatment consisted of the combination of NAA + SA 100 ppm while fourth orange oil extract was used at the rate of $4 \%$ as recommended dose for the field and water spray was done as control.

$100 \mathrm{ppm}$ of these growth promoting substance were prepared by adding $10 \mathrm{mg}$ of the PGR's in $100 \mathrm{ml}$. Stock solution of $1 \mathrm{ppm}$ of these growth promoting substance was prepared by adding $1 \mathrm{~g}$ of PGR's in one liter $(1000 \mathrm{ml})$ of distilled water, from this stock solution 100ppm was prepared by adding $20 \mathrm{ml}$ from stock solution in $180 \mathrm{ml}$ while $4 \%$ of orange oil extract was prepared by mixing $4 \mathrm{ml}$ of orange oil in $96 \mathrm{ml}$ of distilled water. Two to three drops of Tween-20 were also added in all these solutions because tween-20 is a detergent (surfactant) commonly added to buffers and reagents for immune his to-chemistry. Its purpose is to decrease background staining and enhance reagent spreading in automated and manual procedures. The crop was sprayed with different growth regulators in early morning to promote the entry of PGR in the plant surface and to avoid transpiration. The crop was sprayed at four different stages viz., four leaves, flower initiation, flower and fruit initiation stage.

\section{Data collection of parameters studied}

The data was collected on some physical and chemical parameters during these investigations.

\section{Physical parameters}

Vine length (feet): Three plants were randomly chosen from each experimental block and tagged. The vine length of each selected plant was measured (from soil to tip) with the help of a measuring tape 60 days after transplanting and averaged.

Chlorophyll contents: The chlorophyll contents of five leaves from each selected plant was determined without detaching from the plant with the help of chlorophyll meter (SPAD-502 plus, Minolta, Japan) and averaged.

Fresh weight of leaf (g): Five leaves were taken from each plant and their weight was measured with an electrical weighing balance and averaged.

Dry weight of leaf $(\mathrm{g})$ : The leaves used for recording fresh weight were oven dried for 72 hours at $65{ }^{\circ} \mathrm{C}$ then weighed and averaged.

Fresh weight of fruit (g): Three fruits were randomly selected from tagged plants and weighed using an electrical weighing balance and averaged.

Fruit length ( $\mathbf{m m})$ : The same fruits were also used to measure fruit length with the measuring tape and averaged.

\section{Bio-chemical parameters}

Assay for SOD: The leaf SOD activity will be determined based on its effectiveness in inhibiting the photoreduction of nitro blue tetrazolium (NBT). Upon the addition of riboflavin into a test tube containing 3 $\mathrm{mL}$ reaction mixture $(50 \mathrm{mM}$ phosphate buffer $(\mathrm{pH}$ 7.8), $0.1 \mathrm{mM}$ EDTA, $130 \mathrm{mM}$ methionine, $0.75 \mathrm{mM}$ NBT, $0.02 \mathrm{mM}$ riboflavin, and $0.1 \mathrm{~mL}$ of the enzyme 
extract), the $40 \mathrm{~W}$ fluorescent lamps will be used for illumination for $10 \mathrm{~min}$. Non-illuminated and illuminated reactions without the enzyme extract serve as calibration standards. The absorbance values of the reaction mixture and the blank control will be measured with Spectrophotometer at $560 \mathrm{~nm}$. One unit of SOD activity (U) is defined as the amount of enzyme required to cause $50 \%$ inhibition of the NBT photoreduction rate, and the results were expressed as $\mathrm{U}$ $\mathrm{mg}^{-1}$ of FW (Giannopolitis and Ries, 1997).

Assay for POD: POD activity will be determined by measuring the increase in absorbance at $470 \mathrm{~nm}$ due to formation of tetra-guaiacol, an oxidation product of guaiacol. The reaction mixture contains $33.0 \mathrm{mM}$ potassium phosphate buffer ( $\mathrm{pH} 6.1$ ), $16 \mathrm{mM}$ guaiacol, $2 \mathrm{mM} \mathrm{H}_{2} \mathrm{O}_{2}$, and $200 \mu \mathrm{L}$ of enzyme extract. The increase in absorbance at $470 \mathrm{~nm}$ is monitored for 3 min with and without addition of enzyme extract. One unit of POD was defined as the amount of enzyme which consumes $1 \mu \mathrm{mol}$ of $\mathrm{H}_{2} \mathrm{O}_{2}$ per min at $\mathrm{pH} 6.1$ at $25^{\circ} \mathrm{C}$. POD activity $\left(\mu \mathrm{mol} \mathrm{H}_{2} \mathrm{O}_{2}\right.$ decomposed $\mathrm{min}^{-1} \mathrm{mg}^{-1}$ protein) was calculated using the extinction coefficient of $26.6 \mathrm{mM}^{-1} \mathrm{~cm}^{-1}$ Chance and Maehly (1955).

Assay for CAT: CAT activity will be assayed by measuring the rate of decomposition of $\mathrm{H}_{2} \mathrm{O}_{2}$. The reaction mixture consists of $50 \mathrm{mM}$ potassium phosphate buffer ( $\mathrm{pH} \mathrm{7.0),} 12 \mathrm{mM} \mathrm{H}_{2} \mathrm{O}_{2}$, and $50 \mu \mathrm{L}$ of enzyme extract. The rate of disappearance of $\mathrm{H}_{2} \mathrm{O}_{2}$ is followed by observing the rate of decrease in the absorbance at $240 \mathrm{~nm}$ for $3 \mathrm{~min}$. One unit of CAT is defined as the amount of enzyme which decomposes $1 \mu \mathrm{mol} \mathrm{H} \mathrm{O}_{2} \mathrm{~min}^{-1}$ at $\mathrm{pH} 7.0$ at $25^{\circ} \mathrm{C}$. An extinction coefficient of $43.6 \mathrm{M}^{-1} \mathrm{~cm}^{-1}$ was used for calculating the CAT activity ( $\mu \mathrm{mol} \mathrm{min}^{-1} \mathrm{mg}^{-1}$ protein) Chance and Maehly (1955).

Assay for PAL: For the estimation of PAL activity leaf sample $(1 \mathrm{~g})$ will be homogenized in $3 \mathrm{~mL}$ of ice cold $0.1 \mathrm{M}$ sodium borate buffer, $\mathrm{pH} 7.0$ containing $1.4 \mathrm{~m} \mathrm{M}$ of 2-mercaptoethanol and $0.1 \mathrm{~g}$ of insoluble polyvenylpyrrolidone. The extract filter through cheese cloth and the filtrate centrifuge at $12000 \mathrm{rpm}$ for $15 \mathrm{~min}$. The supernatant will be used as enzyme source. PAL activity will be determined as the rate of conversion of $\mathrm{L}$-phenylalanine to trans-cinnamic acid at $290 \mathrm{~nm}$ as described by Dickerson et al. (1984). Sample containing $0.4 \mathrm{~mL}$ of enzyme extract incubate with $0.5 \mathrm{~mL}$ of $0.1 \mathrm{M}$ borate buffer, $\mathrm{pH} 8.8$ and
$0.5 \mathrm{~mL}$ of $12 \mathrm{~m} \mathrm{M} \mathrm{L-phenylalanine} \mathrm{in} \mathrm{the} \mathrm{same} \mathrm{buff-}$ er for $30 \mathrm{~min}$ at $30^{\circ} \mathrm{C}$. The amount of trans-cinnamic acid synthesize will be calculated using its extinction coefficient of $9630 \mathrm{~m}^{-1}$. Enzyme activity was expressed as nmol trans-cinnamic acid $\mathrm{min}^{-1} \mathrm{mg}^{-1}$ protein.

Assay for PPO: PPO activity will be determined as per the procedure given by Mayers et al. (1965). Leaf sample $(1 \mathrm{~g})$ will be homogenized in $2 \mathrm{~mL}$ of $0.1 \mathrm{M}$ sodium phosphate buffer $(\mathrm{pH}$ 6.5) and centrifuge at $12000 \mathrm{rpm}$ for $15 \mathrm{~min}$ at $4^{\circ} \mathrm{C}$. The supernatant will be used as the enzyme source. The reaction mixture consists of $200 \mu \mathrm{L}$ of the enzyme extract and $1.5 \mathrm{~mL}$ of $0.1 \mathrm{M}$ sodium phosphate buffer ( $\mathrm{pH}$ 6.5). To start the reaction, add $200 \mu \mathrm{L}$ of $0.01 \mathrm{M}$ catechol and the activity will be expressed as changes in absorbance at $495 \mathrm{~nm} \mathrm{~min}^{-1} \mathrm{mg}^{-1}$ protein.

\section{Estimation of total phenol}

Leaf samples $(0.5 \mathrm{~g})$ will be homogenized in $2 \mathrm{~mL}$ of $80 \%$ methanol and agitated for $15 \mathrm{~min}$ at $70^{\circ} \mathrm{C}$ (Singleton et al., 1999). One $\mathrm{mL}$ of the methanolic extract will be added to $5 \mathrm{~mL}$ of distilled water and $250 \mu \mathrm{L}$ of Folin-Ciocalteau reagent $(1 \mathrm{~N})$ and the solution will be kept at $25{ }^{\circ} \mathrm{C}$. The absorbance of the developed blue color was measured using a spectrophotometer at $725 \mathrm{~nm}$. Gallic acid is used as the standard. The amount of phenolics will be expressed as $\mu$ g gallic acid $\mathrm{mg}-{ }^{1}$ protein. Bradford (1976) method will be used for the detection of total proteins.

\section{Estimation of total protein}

The modified Folin-Ciocalteu assay was used in this investigation (Singleton et al., 1999). Gallic acid (Sigma-Aldrich, USA) stock solution, $(1 \mathrm{mg} / 10 \mathrm{ml})$ and working standard concentrations of $0,10,25,50$ (ppm) were made in distilled water to prepare the gallic acid calibration standard curve. A sample of $0.5 \mathrm{~g}$ was homogenized in $2.0 \mathrm{ml} 70 \%$ ethanol (Merck, Germany) to prepare the plant extract and incubated for two hours in water bath at $65^{\circ} \mathrm{C}$. The samples were centrifuged at $14000 \mathrm{rpm}$ for five minutes in centrifuge tubes (Centurion, UK). An amount of $4000 \mu \mathrm{l}$ of Folin - Ciocalteu phenol reagent (Sigma - Aldrich, USA) was added to one $\mathrm{ml}$ of supernatant taken from the sample, kept for seven minutes at room temperature and later $4 \mathrm{ml}$ of sodium carbonate was added in the treated sample. Test tubes were shaked vigorously and incubated in darkness for two hrs. Optical density of test sample of each variety was determined at $765 \mathrm{~nm}$ using the spectrophotometer (UV 300, ORI, 
Germany). Total phenolics concentration (w/v), absolute weight was determined based on standard concentration of gallic acid (Krantev et al., 2006).

\section{Statistical analysis}

All the collected datasets were analyzed by analysis of variance (ANOVA) and the treatments means were compared by least significant difference (LSD) test at $5 \%$ level of probability using the SAS (Statistical Analysis System, 8.1 Carry Inc. USA).

\section{Results and Discussion}

To evaluate the effect of foliar application of Naphthalene Acetic Acid, Salicylic acid (SA), combination of Naphthalene Acetic Acid and salicylic acid and orange oil extract, some physical and chemical parameters viz., vine length, chlorophyll contents, fresh weight of leaf, dry weight of leaf, fresh weight of fruit, fruit length, total phenolic contents, total protein contents, superoxide dismutase (SOD) and peroxidase (POD), catalase (CAT) were studied, The effect of Naphthalene Acetic Acid on vine length is 12.66 feet while chlorophyll content were measured 72.50 SPAD Value, while fresh weight of leaves is $5.1 \mathrm{~g}$, dry weight is $0.41 \mathrm{~g}$, while fresh weight of fruit is 121.66 $\mathrm{g}$ and fruit length is $14.11 \mathrm{~cm}$. By applying Salicylic acid on vine length is 11.33 feet while chlorophyll content was calculated as 71.09 (SPAD Value), while fresh weight of leaves was $4.9 \mathrm{~g}$, dry weight was $0.38 \mathrm{~g}$ while fresh weight of fruit was 113.34g and fruit length was $9.80 \mathrm{~cm}$. However, when the combination of Naphthalene Acetic Acid and Salicylic acid was used, vine length was measured 13.99 feet while chlorophyll content give value of 73.99 SPAD Value, while fresh weight of leaves is $5.70 \mathrm{~g}$, dry weight is $0.46 \mathrm{~g}$, while fresh weight of fruit is $123.44 \mathrm{~g}$ and fruit length is $13.22 \mathrm{~cm}$. The result of Orange oil extract application on vine length was 11.99 feet while chlorophyll content gives SPAD value of 70.06 , while fresh weight of leaves was $4.7 \mathrm{~g}$, dry weight was $0.36 \mathrm{~g}$, while fresh weight of fruit was $116.13 \mathrm{~g}$ and fruit length was $12.22 \mathrm{~cm}$. While the control treatment result was on vine length is 9.8 feet while chlorophyll content give value of SPAD 64.06, while fresh weight of leaves was $4.4 \mathrm{~g}$, dry weight is $0.29 \mathrm{~g}$ while fresh weight of fruit was $109.11 \mathrm{~g}$ and fruit length was $7.40 \mathrm{~cm}$ (Table 1 ).

The effect of Naphthalene Acetic Acid on total phenolic contents is $163.33\left(\mathrm{mg} \mathrm{g}^{-1}\right)$, while the total protein content is $25.33\left(\mathrm{mg} \mathrm{g}^{-1}\right)$ SOD 214.30 (IUmin $^{-1}$ $\mathrm{mg}$ protein $\left.{ }^{-1}\right) 895.52 \mathrm{POD}\left(\mathrm{mmol} \mathrm{min}^{-1} \mathrm{mg}\right.$ protein $\left.^{-1}\right)$ and catalase value is 2159.90 . The effect of Salicylic acid on total phenolic content is $157.84\left(\mathrm{mg} \mathrm{g}^{-1}\right)$, while the total protein content is $26.66\left(\mathrm{mg} \mathrm{g}^{-1}\right) \mathrm{SOD}$ 199.33 (IUmin ${ }^{-1} \mathrm{mg}_{\text {protein }}{ }^{-1}$ ) 811.13 POD (mmol $\mathrm{min}^{-1} \mathrm{mg}$ protein $\left.^{-1}\right)$ and catalase value is 2272.72 . When the combination of Naphthalene Acetic Acid and Salicylic acid were applied the total phenolic content is $167.33\left(\mathrm{mg} \mathrm{g}^{-1}\right)$, while the total protein content is $29.80\left(\mathrm{mg} \mathrm{g}^{-1}\right) \mathrm{SOD} 217.25\left(\mathrm{IUmin}^{-1} \mathrm{mg} \mathrm{protein}^{-1}\right)$ 966.82 POD ( $\mathrm{mmol} \mathrm{min}^{-1} \mathrm{mg}$ protein $\left.{ }^{-1}\right)$ and catalase value is 2567.24 . The effect of orange oil extract on total phenolic content is $153.33\left(\mathrm{mg} \mathrm{g}^{-1}\right)$, while the total protein content is $23.44\left(\mathrm{mg} \mathrm{g}^{-1}\right)$ SOD 197.98 $\left(\mathrm{IUmin}^{-1} \mathrm{mg}\right.$ protein $\left.{ }^{-1}\right)$ POD $801.33\left(\mathrm{mmol} \mathrm{min}{ }^{-1}\right.$ $\mathrm{mg}$ protein $\left.^{-1}\right)$ and catalase value is 2417.81 . While the effect of control extract on total phenolic content is $142.33\left(\mathrm{mg} \mathrm{g}^{-1}\right)$, while the total protein content is $21.33\left(\mathrm{mg} \mathrm{g}^{-1}\right)$ SOD $187.53\left(\mathrm{IUmin}^{-1} \mathrm{mg}\right.$ protein $\left.^{-1}\right)$ POD $793.52\left(\mathrm{mmol} \mathrm{min}^{-1} \mathrm{mg}\right.$ protein $\left.^{-1}\right)$ and catalase value is 1488.47 (Table 2).

Luffa acutangula commonly known as ridge gourd is additionally referred to as turai or even luffa. It's really a dark green, ridged vegetable possessing white pulp along with white seeds baked into its soft flesh, extremely fibrous to consume. Ridge gourd is quite lower in saturated fats as well as calories and abundant with dietary fiber, Vitamin-C, minerals, riboflavin, zinc, thiamin, iron, as well as magnesium. During the current research the impact of different plant growth promoting substances were studied and their efficacy at different concentrations was evaluated at luufa plants under the field conditions. Foliar application of Naphthalene Acetic Acid,Salicylic acid (SA), combination of Naphthalene Acetic Acid and salicylic acid and orange oil extract, some physical and chemical parameters viz., vine length, chlorophyll contents, fresh weight of leaf, dry weight of leaf, fresh weight of fruit, fruit length, total phenolic contents, total protein contents, superoxide dismutase (SOD) and peroxidase (POD), catalase (CAT) were studied. Naphthalene Acetic Acid on vine length is 12.66 feet while chlorophyll content was measured 72.50 SPAD Value, while fresh weight of leaves is $5.1 \mathrm{~g}$, dry weight is $0.41 \mathrm{~g}$, while fresh weight of fruit is $121.66 \mathrm{~g}$ and fruit length are $14.11 \mathrm{~cm}$. By applying Salicylic acid on vine length is 11.33 feet while chlorophyll content was calculated as 71.09 (SPAD Value), while fresh weight of leaves was $4.9 \mathrm{~g}$, dry weight was $0.38 \mathrm{~g}$ while fresh weight of fruit was $113.34 \mathrm{~g}$ and fruit length was $9.80 \mathrm{~cm}$. 
Table 1: Effect of various treatments on the physical parameters of the luffa plants.

\begin{tabular}{|c|c|c|c|c|c|c|}
\hline Treatments & $\begin{array}{l}\text { Vine length } \\
\text { (feet) }\end{array}$ & $\begin{array}{l}\text { Chlorophyll con- } \\
\text { tents (SPAD Values) }\end{array}$ & $\begin{array}{l}\text { Fresh } \\
\text { weight }(g)\end{array}$ & $\begin{array}{l}\text { Dry } \\
\text { weight (g) }\end{array}$ & $\begin{array}{l}\text { Fresh weight } \\
\text { of fruit (g) }\end{array}$ & $\begin{array}{l}\text { Fruit } \\
\text { length }(\mathrm{cm})\end{array}$ \\
\hline Naphthalene Acetic Acid & $12.66 \mathrm{~b}$ & $72.50 \mathrm{~b}$ & $5.1 \mathrm{~b}$ & $0.41 \mathrm{~b}$ & $121.66 \mathrm{~b}$ & $14.11 \mathrm{a}$ \\
\hline Salicylic acid & $11.33 \mathrm{~d}$ & $71.09 \mathrm{c}$ & $4.9 \mathrm{c}$ & $0.38 \mathrm{c}$ & $113.34 \mathrm{~d}$ & $9.80 \mathrm{c}$ \\
\hline Naphthalene Acetic Acid + Salicylic acid & $13.99 \mathrm{a}$ & $73.99 \mathrm{a}$ & $5.7 \mathrm{a}$ & $0.46 \mathrm{a}$ & $123.44 \mathrm{a}$ & $13.22 \mathrm{~b}$ \\
\hline Orange oil extract & $11.99 \mathrm{c}$ & $70.06 \mathrm{~d}$ & $4.7 \mathrm{~d}$ & $0.36 \mathrm{~d}$ & $116.13 \mathrm{c}$ & $12.22 \mathrm{bc}$ \\
\hline Control & $9.8 \mathrm{e}$ & $64.06 \mathrm{e}$ & $4.4 \mathrm{e}$ & $0.29 \mathrm{e}$ & $109.11 \mathrm{e}$ & $7.40 \mathrm{~d}$ \\
\hline LSD* & 3.99 & 16.66 & 1.12 & 0.99 & 13.33 & 6.66 \\
\hline
\end{tabular}

*Means followed by the same letter in each column are not statistically different at P<0.05; LSD: Least significant difference.

Table 2: Effect of various treatments on the biochemical parameters of the luffa plants.

$\begin{array}{llllll}\text { Treatments (mg/liter) } & \text { Total phenolic } & \text { Total protein } & \text { *SOD } & \text { *POD } & \text { Catalase } \\ \text { Naphthalene Acetic Acid } & 163.33 \mathrm{~b} & 25.33 \mathrm{c} & 214.30 \mathrm{~b} & 895.52 \mathrm{~b} & 2159.90 \mathrm{~d} \\ \text { Salicylic acid } & 157.84 \mathrm{c} & 26.66 \mathrm{~b} & 199.33 \mathrm{c} & 811.13 \mathrm{c} & 2272.72 \mathrm{c} \\ \text { Naphthalene Acetic Acid + Salicylic acid } & 167.33 \mathrm{a} & 29.80 \mathrm{a} & 217.25 \mathrm{a} & 966.82 \mathrm{a} & 2567.24 \mathrm{a} \\ \text { Orange oil extract } & 153.33 \mathrm{~d} & 23.44 \mathrm{~d} & 197.98 \mathrm{~d} & 801.33 \mathrm{~d} & 2417.81 \mathrm{~b} \\ \text { Control } & 142.33 \mathrm{e} & 21.33 \mathrm{e} & 187.53 \mathrm{e} & 793.52 \mathrm{e} & 1488.47 \mathrm{e} \\ \text { LSD* } & 17.34 & 8.34 & 22.12 & 236.13 & 177.31\end{array}$

"Means followed by the same letter in each column are not statistically different at P < 0.05; LSD: Least significant difference; SOD: Superoxide dismutase; POD: Peroxidase.

However, when the combination of Naphthalene Acetic Acid and Salicylic acid was used, vine length was measured 13.99 feet while chlorophyll content give value of 73.99 SPAD Value, while fresh weight of leaves is $5.70 \mathrm{~g}$, dry weight is $0.46 \mathrm{~g}$, while fresh weight of fruit is $123.44 \mathrm{~g}$ and fruit length is $13.22 \mathrm{~cm}$. The result of Orange oil extract application on vine length was 11.99 feet while chlorophyll content gives SPAD value of 70.06, while fresh weight of leaves was $4.7 \mathrm{~g}$, dry weight was $0.36 \mathrm{~g}$, while fresh weight of fruit was $116.13 \mathrm{~g}$ and fruit length was $12.22 \mathrm{~cm}$. While the control treatment result was on vine length is 9.8 feet while chlorophyll content give value of SPAD 64.06, while fresh weight of leaves was $4.4 \mathrm{~g}$, dry weight is $0.29 \mathrm{~g}$ while fresh weight of fruit was $109.11 \mathrm{~g}$ and fruit length was $7.40 \mathrm{~cm}$.

The effect of Naphthalene Acetic Acid on total phenolic contents is $163.33\left(\mathrm{mg} \mathrm{g}^{-1}\right)$, while the total protein content is $25.33\left(\mathrm{mg} \mathrm{g}^{-1}\right)$ SOD 214.30 (IU$\mathrm{min}^{-1} \mathrm{mg}$ protein $\left.{ }^{-1}\right)$ 895.52 POD $\left(\mathrm{mmol} \mathrm{min} \mathrm{mg}^{-1} \mathrm{mg}\right.$ protein $^{-1}$ ) and catalase value is 2159.90 . The effect of Salicylic acid on total phenolic content is $157.84(\mathrm{mg}$ $\left.\mathrm{g}^{-1}\right)$, while the total protein content is $26.66\left(\mathrm{mg} \mathrm{g}^{-1}\right)$ SOD $199.33\left(\right.$ IUmin $^{-1} \mathrm{mg}$ protein $\left.^{-1}\right)$ 811.13 POD $\left(\mathrm{mmol} \mathrm{min}^{-1} \mathrm{mg}\right.$ protein $\left.{ }^{-1}\right)$ and catalase value was 2272.72. When the combination of effect of Naph- thalene Acetic Acid and Salicylic acid are applied the total phenolic content is $167.33\left(\mathrm{mg} \mathrm{g}^{-1}\right)$, while the total protein content is $29.80\left(\mathrm{mg} \mathrm{g}^{-1}\right)$ SOD 217.25 $\left(\mathrm{IUmin}^{-1} \mathrm{mg}\right.$ protein $\left.^{-1}\right)$ 966.82 POD $\left(\mathrm{mmol} \mathrm{min}{ }^{-1}\right.$ $\mathrm{mg}$ protein $^{-1}$ ) and catalase value is 2567.24 . The effect of orange oil extract on total phenolic content is $153.33\left(\mathrm{mg} \mathrm{g}^{-1}\right)$, while the total protein content is $23.44\left(\mathrm{mg} \mathrm{g}^{-1}\right)$ SOD $197.98\left(\right.$ IUmin $^{-1} \mathrm{mg}$ protein $\left.^{-1}\right)$ POD $801.33\left(\mathrm{mmol} \mathrm{min}^{-1} \mathrm{mg}\right.$ protein $\left.{ }^{-1}\right)$ and catalase value is 2417.81 . While the effect of control extract on total phenolic content is $142.33\left(\mathrm{mg} \mathrm{g}^{-1}\right)$, while the total protein content is $21.33\left(\mathrm{mg} \mathrm{g}^{-1}\right)$ SOD 187.53 $\left(\mathrm{IUmin}^{-1} \mathrm{mg}\right.$ protein $\left.{ }^{-1}\right)$ POD $793.52\left(\mathrm{mmol} \mathrm{min}^{-1} \mathrm{mg}\right.$ protein $\left.^{-1}\right)$ and catalase value is 1488.47 . Our results are in line with Ram and Mehta (1978), who recorded increase in number of branches per plant as a response to foliar application of $\mathrm{GA}_{3}$ which was possibly due to the breakup of dormancy of lateral shoot buds. Mohammed (2013) noted after foliar application of AA increase in fruit length of Capsicum annum. This was probably due to the auxinic action of AA on enhancing the cell division and elongation. Similarly, foliar spray of SA has been found to increase fruit length in tomato (Yildirim and Dursun, 2009). In prior findings SA and AA separately, increased fruit length. In the present investigation these substances enhanced the fruit length in eggplant when applied in 
combination. Like these result, Javaheri et al. (2012) and Yildirim and Dursun (2009) reported that yield of tomato improved by the application of SA. In various plant species SA induces flowering which results in an increased in fruit number and yield (Hayat et al., 2007). Similarly, GABA enhances endogenous hormones of plants, which affect growth, physiological attributes and finally yield. GABA $(0.33 \mathrm{~mL} \mathrm{~L}-1)$ enhanced the growth, yield and yield attributes of wheat in Bangladesh as reported by Hoque (2002), Sekh (2002), Dakua (2002) and Islam (2007) also published similar reports in rice, lentil, barley and onion.

\section{Conclusion}

It is concluded that the application of growth promoting substances either applied singly or in combination with others in the field conditions promotes not only the growth of the vegetable crops but also the average yield.

\section{Acknowledgments}

Special thanks are due to Miss. Sadaf for her cooperation and timely help during the entire course of research.

\section{Author's Contribution}

Safina Naz and Syed Atif Hasan Naqvi conceived the idea. The experiments were performed by Khushbo Hussain while SPSS analysis was performed by Syed Atif Hasan Naqvi and the reference section and management was done by Muhammad Asif Zulfiqar

\section{References}

Abro, G.H., T.S. Syed, M.I. Umer and J. Zhang. 2004. Effect of application of a growth regulator and micronutrients on insect pest infestation and yield components of cotton. J. Entomol. 1(1): 12-16. https://doi.org/10.3923/ je.2004.12.16

Alam, S.M., A. Shereen and M. Khan. 2002. Growth response of wheat cultivars to naphthalene acetic acid (NAA) and ethrel. Pak. J. Bot. 34(2): 135-137.

Arshad, M. and J. Frankenberger. 1993. Microbial production of plant growth regulators: 307-347. In: Soil Microbial Echol. F.B. Metting Jr.(Ed), Marcel Dekker Inc., N.Y.
Bradford, M.M. 1976. A rapid and sensitive method for the quantitation of microgram quantities of protein utilizing the principle of protein-dye binding. Analyt. Bio. chem. 72: 248-254.

Chance, B.C. and Maehly. 1955. Assay of catalase and peroxidases. Methods Charchar, J.M. and F.A.S. Aragao. 2005. Repriduction of Meloidogyne spp. on tomato and cucmber varities under plastic greenhouse and field. Nematol. Brasileir. 29: 243249.

Chaudhary, B.R., M.D. Sharma, S.M. Shakya and D.M. Gautam, 2006. Effect of plant growth regulators on growth, yield and quality of chilli (Capsicum annuum L.) at Rampur, Chitwan. J. Inst. Agric. Ani. Sci. 27: 65-68. https://doi. org/10.3126/jiaas.v27i0.697

Dakua, M.F. 2002. Effect of Brassinosteroids (TNZ-303), chloroindole acetic acid (CI- IAA) and GABA on growth, yield and yield contributing characters of Lentil. MS Thesis, Department of Crop Botany, Bangladesh Agric. Univ. Mymensingh.

Das, B.C. and T.K. Das. 1996. Studies on the response of GA3, NAA and Etherl on thevegetative growth and yield of pumpkin. Orisssa J. Hort. 24: 74-78.

Davies, P.J. 1987. Plant hormone and their role in plant growth and development. Martinus $\mathrm{Ni}^{-}$ jhoff Publ. Dordrecht, Netherlands. https://doi. org/10.1007/978-94-009-3585-3

Dickerson, D.P., S.F. Pascholati, A.E. Hagerman, L.G. Butler and R.L. Nicholson. 1984. Phenylalanine ammonia lyase and hydroxycinnamate: CoA ligase in maize mesocotyls inoculated with Helminthosporium maydis or Helminthosporium carbonum. Physiol. Plant Pathol. 25: 111-123. https://doi.org/10.1016/00484059(84)90050-X

Giannopolitis, C.N. and S.K. Reis 1997. Superoxide dismutase I. Occurrence in higher plants. Plant Physiol. 59, 309-314. https://doi.org/10.1104/ pp.59.2.309

Hayat, S., B. Ali and A. Ahmad. 2007. Salicylic acid: biosynthesis, metabolism and physiological role in plants, In: Hayat, S. andA. Ahmad, (eds.). Salicylic Acid: A Plant Hormone. Springer, Dordrecht, The Netherlands, pp. 1-14.

Hoque, M.M. 2002. Effect of CI-IAA, GABA and TNZ-303 on growth, yield and contributing characters of wheat. $M S$ Thesis, Department of Crop Bot., Bangladesh Agric. Univ. Mymens- 
ingh.

Islam, M.S., M.O. Islam, M.N. Alam, M.K. Ali and M.A. Rahman, 2007. Effect of plant growth regulator on growth, yield and yield components of Onion. Asian J. Plant Sci. 6: 849-853. https://doi.org/10.3923/ajps.2007.849.853

Javaheri, M., K. Mashayekhi, A. Dadkhah and F.Z. Tavallaee. 2012. Effects of salicylic acid on yield and quality characters of tomato fruit (Lycopersicon esculentum Mill.). Int. J. Agric. Crop Sci. 4: 1184-1187.

Krantev, A., R. Yordanova and L. Popova. 2006. Salicylic acid decreases $\mathrm{Cd}$ toxicity in maize plants. Gen. Appl. Plant Physiol. Special Issue: 45-52.

Lilani, A.T., T. Joshi and R.K. Mishra. 1991. NAA-mediating growth and macro molecular changes in wheat primary leaf serial section. Indian J. Plant Physiol. 34: 311-318

Michiewicz, M. and B. Rozej. 1987. Further studies on the role of auxin onthe growth and development of Fusarium culmorum (W.G.Sm.) Sacc. Acta Physiol. Plant. 9, 219-227. Nakamura T, Kawanabe Y, Takiyama E, Takahashi N, Murayama T. 1978. Effects of auxin and gibberellin on conidial germination in Neurospora crassa. Plant Cell Physiol. 19. 705-709.

Mohammed, G.H. 2013. Effect of seamino and ascorbic acid on growth, yield and fruit quality of pepper (Capsicum annum L). Int. J. Pure Appl. Sci. Technol. 17: 9-16.

Mayers, A.M., E. Harel and R.B. Shaul. 1995. Assay of catechol oxidase a critical comparison of methods. Phytochem. 5. 783-789. https://doi.
org/10.1016/S0031-9422(00)83660-2

Ram, H.Y.M. and U. Mehta, 1978. Effect of gibberellic acid on the growth of main shoot and axillary branches in Calendula officinalis. Proc. India. Acad. Sci. Section B, 87: 255-270.

Rafeekher, M., S.A. Nair, P.N. Sorte, G.P. Hatwal and P.M. Chandhan. 2002. Effect of growth regulators on growth and yield of summer $\mathrm{cu}^{-}$ cumber. J. Soils Crops. 12: 108-110.

Sekh, M.H.R. 2002. Effect of CI-IAA, TNZ-303 and GABA on seed germination and seedling growth of different varieties of aman rice. $M S$ Thesis, Department of Crop Bot., Bangladesh Agric. Univ. Mymensingh.

Singleton, V.L., R. Orthofer and R.M. Raventos. 1999. Analysis of total phenolics and other oxidation substrates and antioxidants by means of Folin-Ciocalteu reagent. Methods Enzymol. 299: 152-178. https://doi.org/10.1016/S00766879(99)99017-1

Tiaz, L. and E. Zeiger. 2002. Plant Physiology. 3rd Ed. Sinauer Association Inc. Publisher Massachusetts. USA.

Yildirim, E. and A. Dursun. 2009. Effect of foliar salicylic acid applications on plant growth and yield of tomato under greenhouse conditions. Acta Horticulturae. 807: 56.

Zahir, Z.A., A. Rahman, N. Asghar, M. Arshad. 1998. Effect of an auxin precursor L-tryptophan on growth and yield of rice. Pak. J. Biol. Sci. 1(4): 354-356. https://doi.org/10.3923/ pjbs.1998.354.356 